\title{
Wpływ kryzysu na funkcjonowanie korporacji Panasonic
}

Współczesne procesy rozwoju gospodarczego uruchamiają w przestrzeni światowej procesy polaryzacji. Kapitał międzynarodowy koncentruje się w coraz prężniej rozwijających się biegunach wzrostu, które są głównym źródłem światowego postępu technologicznego i tworzenia nowych produktów kierowanych na globalny rynek. W ten sposób spełniają funkcje uczestników światowego handlu, a przede wszystkim są głównymi ośrodkami eksportu dóbr i usług oraz obrotów kapitałowych. Wyodrębniamy 3 centra: Stany Zjednoczone, Europę Zachodnią oraz Japonię, nazywane Triadą. Z krajów Triady wywodzi się większość korporacji transnarodowych (głównie ze Stanów Zjednoczonych oraz Japonii) (Czarny 2004; Zioło 2008; Kilar 2009, 2010; Wajda 2003, 2006; Wajda, Zoričič-Wołek 2003).

W związku z tym, że korporacje ponadnarodowe są jednym z wiodących elementów gospodarki światowej, zarówno organizują one światową przestrzeń gospodarczą jak również polegają tendencjom w niej występującym. Na funkcjonowanie gospodarki światowej w czasie współczesnego kryzysu szczególny wpływ miało załamanie się rynków finansowych, bardzo silnie powiązanych z korporacjami wszystkich branż (Flejterski 2010; Kalicki, Krześniak 2010; Kutera, Surydykowska 2009; Michalski 2010; Rosati 2010). Recesja na rynku globalnym przejawiała się m.in. tym, że firmy, niejednokrotnie o ustalonej pozycji, borykały się z problemami finansowymi, a niektóre nawet zbankrutowały. Większość przedsiębiorstw musiało podjąć szybkie działania, by poprawić swoją sytuację finansową, a niektóre korporacje ponadnarodowe zmuszone były do zmiany strategii rozwoju, przez co wpływały na lokalne rynki pracy, co w przypadku korporacji było szczególnie istotne ze względu na efekty mnożnikowe, które są wynikiem ich działalności (jedna osoba zatrudniona w korporacji motoryzacyjnej tworzy około czterech miejsc pracy w innych gałęziach gospodarki), co podkreślają liczni autorzy (Dorocki 2010; Wiedermann 2007, 2008; Rachwał 2009, 2010; Domański, Gwosdz 2008).

W świetle powyższych przesłanek przedmiotem niniejszych rozważań będzie analiza wpływu kryzysu na funkcjonowanie jednej z japońskich korporacji informatycznych Panasonic. Zmierzać się będzie do analizy zmian jej potencjału ekonomicznego oraz przedstawienia działań, które miały poprawić jej sytuację finansową.

Panasonic został założony w 1918 r. Założycielem korporacji był Konosuke Matsushita, który urodził się w 1895, jako syn właściciela niewielkich dóbr ziemskich. Gdy Konosuke był jeszcze małym dzieckiem, jego ojciec, spekulując na rynku towarów podstawowych, stracił cały majątek rodziny. Po utracie posiadłości rodzina przeniosła się do niewielkiego 
domu położonego w najbliższym mieście, a młody Konosuke, aby wspomóc rodzinny budżet, został wysłany do pracy w sklepie rowerowym. Mając 15 lat porzucił jednak to zajęcie i podjął pracę na stanowisku technika zajmującego się przyłączaniem nowych punktów do sieci w Osaka Electric Light Company. W ciagu 7 lat awansował na najwyższe dostępne dla technika stanowisko inspektora. Ze względu na brak dalszych perspektyw zawodowych w dotychczasowym miejscu pracy postanowił założyć własną firmę: Matsushita Electric.

Firma od początku swego istnienia przywiązywała szczególną wagę do wprowadzania na rynek nowoczesnych i konkurencyjnych produktów, mimo że zgromadzone oszczędności w wysokości 100 jenów wystarczyły na urządzenie skromnego warsztatu, gdzie produkowano wtyczki przyłączeniowe. Na początku z powodu słabej sprzedaży firma była bliska bankructwa, lecz zamówienie na 1000 izolatorów przeznaczonych dla elektrycznych wentylatorów zapewniło dalsze jej funkcjonowanie. Kolejne zamówienia spowodowały zwiększenie płynności finansowej, dzięki czemu podjęto nowe inwestycje, jakimi było wynajęcie piętrowego domu na przedmieściach Osaki i rozpoczęcie produkcji dwudrożnego gniazdka, które z racji wysokiej jakości i niższej od 30\% do 50\% ceny w porównaniu do konkurencyjnych modeli okazało się rynkowym sukcesem. Następnymi produktami, które również odniosły sukces, były m.in. bateryjna lampa rowerowa, pierwsze masowo produkowane żelazko elektryczne i pierwsze trzylampowe radio. W wyniku dywersyfikacji produkcji oświetlenia rowerowego i elektrycznego firma stała się bezpośrednim dostawcą dużych sieci sprzedaży detalicznej w Japonii, które dotychczas były zdominowane przez większe firmy. Poprzez stworzenie silnej konkurencji dzięki oferowanym zniżkom przedsiębiorstwo zdobyło duży udział w rynku. Tuż przed wybuchem II wojny światowej, po wprowadzeniu na rynek serii udanych, innowacyjnych produktów firma, która w międzyczasie zmieniła nazwę na Matsushita Electric Industrial Co. Ltd, miała już ugruntowaną pozycję na rynku krajowym. W czasie wojny, jak wszystkie japońskie firmy, również Matsushita Electric Industrial Co., Ltd zmuszona była dostosować profil swojej produkcji do realiów gospodarki wojennej. Po zakończeniu działań zbrojnych, kiedy władzę w Japonii przejęli alianci, Matsushita Electric Industrial została zaklasyfikowana, do grupy zaibatsu, tj. wielkich konglomeratów przemysłowo-bankowych kontrolowanych przez pojedyncze rodziny. Decyzją władz skonfiskowano majątki rodzin, eliminowano holdingi pełniące rolę dominującą dla poszczególnych zaibatsu, a rady dyrektorów, kluczowe dla tego systemu opierającego się na koordynacji między przedsiębiorstwami, zostały prawnie zabronione. Również Konosuke Matsushita stracił kontrolę nad firmą, którą zbudował od podstaw. Jednakże związki zawodowe w firmie, które silnie wspierały Matsushitę, zagroziły strajkiem i sporządziły petycję podpisaną przez 15 tys. pracowników, dzięki czemu koncern wrócił w ręce dotychczasowego właściciela.

Po wojnie najważniejszym zadaniem spółki było odbudowanie sprzedaży w kraju oraz skierowanie swoich produktów na rynki zagraniczne. W 1951 r., po podróży Konosuke Matsushity do Stanów Zjednoczonych, gdzie miał okazję obserwować nowoczesny amerykański przemysł, postanowiono przenieść niektóre innowacyjne rozwiązania na grunt japoński. W tym celu w 1952 r. podpisano pierwszą umowę o współpracy pomiędzy Matsushita Electric Industrial Co., Ltd a holenderską firmą Philips. Rok później z powodzeniem wprowadzono na rynek japoński pralki, telewizory i lodówki, w następnym odkurzacze. Poza tym w 1954 r. wykupiono 50\% udziałów mającej kłopoty finansowe firmy Japan Victor Company (JVC). Jednak potraktowano ten zakup jako inwestycję, nie zmieniając dotychczasowej struktury, czyli JVC pozostało niezależnie zarządzaną firmą, która nadal była konkurentem firmy Matsushita. Poprawiająca się sytuacja ekonomiczna w Japonii pozwoliła 
planować dalszy rozwój firmy. W 1956 r. ogłoszono plan 5-letni-program zakładający czterokrotne zwiększenie rocznej sprzedaży, wzrost zatrudnienia o 60\% i zwiększenie aktywów z 3 do 10 mld jenów. Choć plan był przewidziany na 5 lat, to już po czterech latach osiagnięto zakładane wyniki dzięki wprowadzeniu linii wysokiej jakości odbiorników radiowych (FM), magnetofonów i systemów z dźwiękami stereo opracowanych przez JVC. W tym okresie (1958 r.) firma zaczęła produkować telewizory kolorowe oraz otworzyła fabryki w mniej rozwiniętych krajach azjatyckich, takich jak Tajwan i Singapur, gdzie koszty pracy były niskie, a lokalna waluta bardziej stabilna wobec dolara. Pod marką National firma sprzedawała swoje produkty na krajowym rynku. Z przychodów generowanych przez sprzedaż w Japonii firma była w stanie sfinansować ambitne plany globalnej strategii.

W 1959 r. została otwarta Matsushita Electric Corporation of America, a w Nowym Jorku zlokalizowano amerykańską siedzibę koncernu. Wtedy też rozpoczęła się dynamiczna zagraniczna ekspansja firmy, o czym świadczy m.in. otwarcie w 1961 i 1962 roku pierwszych zagranicznych firm produkcyjnych National Tai i Matsushita Electric (Tajwan). W 1974 r. Matsushita, chcąc zwiększyć udział w rynku amerykańskim, zakupiła od Motoroli udziały firmie Quasar produkującej telewizory (koszt inwestycji to $100 \mathrm{mln}$ dolarów).

W kolejnych latach wprowadzono na rynek magnetowid z systemem nagrywania kaset wideo do użytku domowego, VHS magnetofon z możliwością 4-godzinnego nagrywania, Thin radio, które dzięki nowej technice montażu było tak małe, że mieściło się w kieszeni, oraz cienkie jak kartka papieru baterie, które zaczęto stosować w kalkulatorach, zegarkach czy aparatach fotograficznych.

W związku z tym, że japoński rynek konsumencki w latach 80. był już nasycony, rozszerzono zakres działalności. Matsushita chciała wejść na rynek półprzewodników, automatyki przemysłowej, maszyn biurowych i sprzętu audiowizualnego. W tym celu rozpoczęto budowę nowego utalentowanego zespołu inżynierów, który zajmował się badaniami i rozwojem w nowo podjętych dziedzinach.

W 1987 r. powstała spółka joint venture z siedzibą w Pekinie - Beijing Matsushita Color CRT, Ltd, która została zawiązana między Matsushita i Chińską Republiką Ludową. Wspólne przedsięwzięcie stworzone było w celu produkcji kineskopów (CRT) do telewizorów najpierw 21", a później większych rozmiarów. Nowa firma, w której zatrudniono około 1400 pracowników, rozpoczęła produkcję w czerwcu 1989 r. Poza tym w latach 80. zaczęto produkować pierwsze odtwarzacze CD i kamery VHS, a z powodu wzrastającej sprzedaży zagranicznej w 1988 r. utworzono trzy regionalne działy zarządzania korporacją: jeden dla obu Ameryk, Europy i Afryki, drugi dla Azji, Oceanii i trzeci na Bliskim Wschodzie. W tym czasie Matsushita była już jednym z największych producentów dóbr konsumpcyjnych na świecie. Szybko rozwijał się również dział elektroniki przemysłowej, który w roku 1989 stanowił 35\% sprzedaży.

Jednak intensywna konkurencja zmusiła firmę do zmiany dotychczasowej strategii. $\mathrm{Na}$ początku lat 90., kiedy wiele spółek w tej branży dokonywało fuzji (np. konkurent Sony Corp nabył firmy Columbia Pictures Entertainment Inc. i Time Warner Inc. Communications Inc.) Matsushita kupiła firmę MCA Inc., należącą do Hollywood Studios, która miała wprowadzić innowacje w dziedzinie elektronicznej rozrywki poprzez integrację sprzętu i oprogramowania. Jednakże wysokie koszty związane z połączeniem spółek i spadek popytu na produkty audio i wideo oraz pogarszająca się sytuacja gospodarcza w Japonii zmusiły firmę do szybkiej sprzedaży $80 \%$ akcji MCA. 
Ta nietrafiona inwestycja oraz utrzymujący się w drugiej połowie lat 90 . w krajach Azji spadek wartości akcji i nieruchomości spowodowały pogłębianie się recesji. Matsushita odczuła tę sytuację w 1999 r., kiedy to dochód netto zmniejszył się w stosunku do 1997 r. do $17,6 \%$ - z 137, 8 mld jenów w 1997 r. do 24,2 mld jenów (tab. 1, ryc. 1), przy czym wartość sprzedaży była na poziomie około 76 mld jenów, a zatrudnienie wzrosło do $104,2 \%$ z 270,6 tys. do 282,1 tys. osób (ryc. 2) .

Tab. 1. Zmiany wartości sprzedaży, dochodu netto oraz aktywów korporacji

Matsushita Electric Industrial Co. w latach 1997-2010

\begin{tabular}{|c|c|c|c|c|c|c|}
\hline \multirow{2}{*}{ Lata } & \multirow{2}{*}{$\begin{array}{c}\text { Sprzedaż } \\
\text { netto } \\
\text { (Net sales) }\end{array}$} & \multirow{2}{*}{$\begin{array}{c}\text { Dochód/strata } \\
\text { netto } \\
\text { (Net income /loss) }\end{array}$} & \multirow{2}{*}{$\begin{array}{c}\text { Aktywa } \\
\text { (Total assets) }\end{array}$} & \multicolumn{3}{|c|}{$\begin{array}{c}\text { Dynamika w latach } 1997-2010 \\
1997=100 \%\end{array}$} \\
\hline & & & & $\begin{array}{l}\text { Sprzedaż } \\
\text { netto }\end{array}$ & $\begin{array}{c}\text { Dochód/strata } \\
\text { netto }\end{array}$ & Aktywa \\
\hline 1997 & 7675912 & 137853 & 8856524 & 100,0 & 100,0 & 100,0 \\
\hline 1998 & 7890662 & 99347 & 8660518 & 102,8 & 72,1 & 97,8 \\
\hline 1999 & 7640119 & 24246 & 8054529 & 99,5 & 17,6 & 90,9 \\
\hline 2000 & 7404958 & 106191 & 8076414 & 96,5 & 77,0 & 91,2 \\
\hline 2001 & 7780519 & 41503 & 8295044 & 101,4 & 30,1 & 93,7 \\
\hline 2002 & 7073837 & -427779 & 7768457 & 92,2 & $-310,3$ & 87,7 \\
\hline 2003 & 7401714 & -19453 & 7834693 & 96,4 & $-14,1$ & 88,5 \\
\hline 2004 & 7479744 & 42145 & 7438012 & 97,4 & 30,6 & 84,0 \\
\hline 2005 & 8713636 & 58481 & 8056881 & 113,5 & 42,4 & 91,0 \\
\hline 2006 & 8894329 & 154410 & 7964640 & 115,9 & 112,0 & 89,9 \\
\hline 2007 & 9108170 & 217185 & 7896958 & 118,7 & 157,5 & 89,2 \\
\hline 2008 & 9068928 & 281877 & 7443614 & 118,1 & 204,5 & 84,0 \\
\hline 2009 & 7765507 & -378961 & 6403316 & 101,2 & $-274,9$ & 72,3 \\
\hline 2010 & 7417980 & -170667 & 8358057 & 96,6 & $-123,8$ & 94,4 \\
\hline
\end{tabular}

Źródło: opracowanie własne na podstawie danych ze sprawozdań finansowych firmy

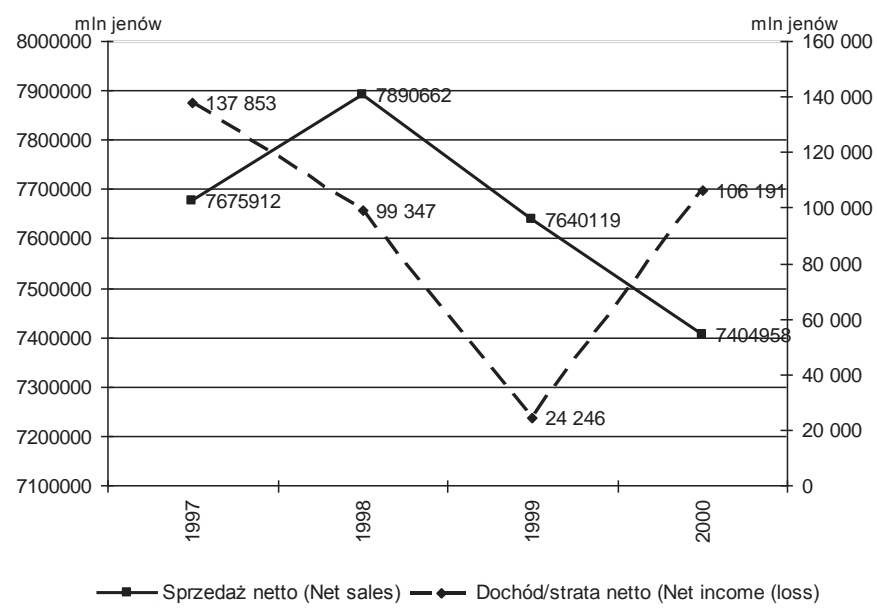

Ryc. 1. Zmiany wartości dochodu netto oraz sprzedaży korporacji

Matsushita Electric Industrial Co. w latach 1997-2000

Źródło: opracowanie własne na podstawie danych ze sprawozdań finansowych firmy 


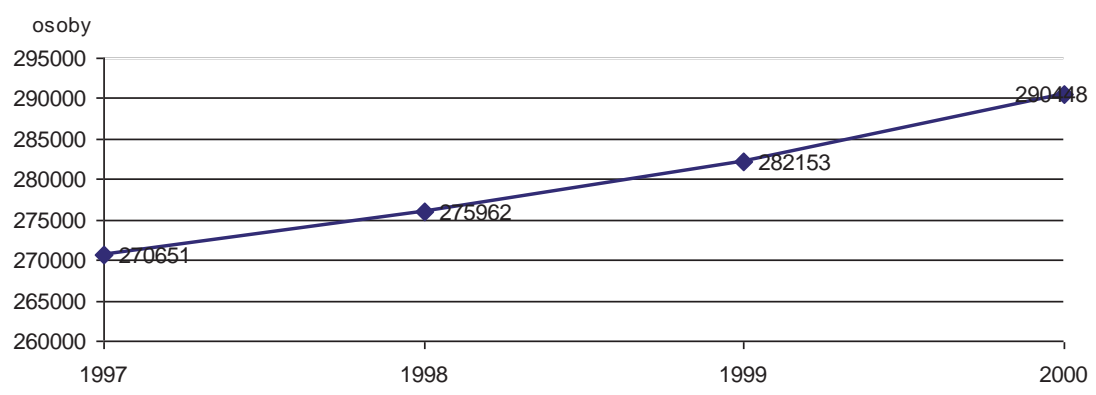

Ryc. 2. Zmiany zatrudnienia korporacji Matsushita Electric Industrial Co. w latach 1997-2000

Źródło: opracowanie własne na podstawie danych ze sprawozdań finansowych firmy

Wówczas Matsushita wprowadziła strategię, w której sformalizowano sposoby radzenia sobie z trudną sytuacją gospodarczą, zakładającą m.in. dalsze koncentrowanie się na korporacyjnej misji i obowiązkach wobec społeczeństwa, kontynuowanie wprowadzania innowacyjnych produktów, które są podstawą innowacyjności gospodarki oraz dalsze utrwalanie tradycji Panasonic dotyczącej autonomicznego zarządzania.

Mimo niekorzystnej sytuacji ekonomicznej w latach 90. wprowadzono na rynek m.in. takie produkty jak: notebooki, żarówki typu świetlówki, akumulatory litowo-jonowe, odtwarzacze DVD, telewizory plazmowe, systemy nawigacji do samochodów oraz cyfrowe odbiorniki i tunery (set top box), co, jak można przypuszczać, spowodowało, że wartość sprzedaży nie zmniejszyła się tak bardzo jak ogólne wyniki działalności.

Załamanie rynku przemysłu informatycznego, tj. pęknięcie tzw. bańki internetowej oraz spowolnienie światowe w dziedzinie IT i związanych z nią branżach, a także spadki cen i negatywne skutki ataków terrorystycznych z 11 września 2001 r. w Stanach Zjednoczonych oraz spadek sprzedaży sprzętu telefonii komórkowej wpłynęły na drastyczny spadek wyników korporacji. W latach 2001-2003 zaobserwowano spadek wyniku finansowego netto z 41,5 mld jenów w 2001 r. do -427,7 mld jenów w 2002 r. i -19,4 mld jenów w 2003 r.

Wówczas podjęto decyzję o restrukturyzacji firmy. Wprowadzono nową strategię, w ramach której planowano zamknięcie nierentownych fabryk i wzmocnienie działań zmierzających do rozwoju nowych produktów. Odchodzono od dotychczasowych priorytetów, czyli utrzymania poziomu sprzedaży i liczby pracowników. W ciągu 4 lat korporacja zwolniła w krajowych firmach 27,1 tys. osób, zrywając ze szczególnie rozwiniętym programem ochrony miejsc pracy. Zmniejszono liczbę spółek-córek w Japonii ze 146 do 104. Wówczas zadecydowano również o wycofaniu z rynku większość modeli telefonów komórkowych przeznaczonych do surfowania po Internecie (jeszcze w technologii WAP), ze względu na duże straty wynikające $\mathrm{z}$ tej inwestycji.

Zarząd skoncentrował się na rewitalizacji marki Panasonic, dlatego skupiono się na rynku nagrywarek DVD, płaskich telewizorów i telefonów komórkowych. W ciagu dwóch lat Matsushita odnowiła całą linię produktów na czele z panelami LCD, nagrywarkami DVD i kamerami.

Korporacja stopniowo odbudowywała wyniki finansowe w kolejnych latach. W $2007 \mathrm{r}$. osiagnęła wartość sprzedaży na poziomie 9108,2 mld jenów, a dochód netto wyniósł 217,2 mld jenów (ryc. 3). Kapitał własny był najwyższy od kryzysu w latach 90. i wynosił 3,9 biliona jenów. 
Światowy kryzys gospodarczy w kolejnych latach w znacznym stopniu wpłynął na działalność korporacji. W związku ze spadkiem popytu na urządzenia elektroniczne wartość sprzedaży zmniejszyła się w latach 2007-2010 do 7417,9 mld jenów w 2010 r., tj. do 81,4\% (ryc. 3) oraz dochodów netto firmy do -170,7 mld jenów w 2010 r., tj. o 387,9 mld jenów.

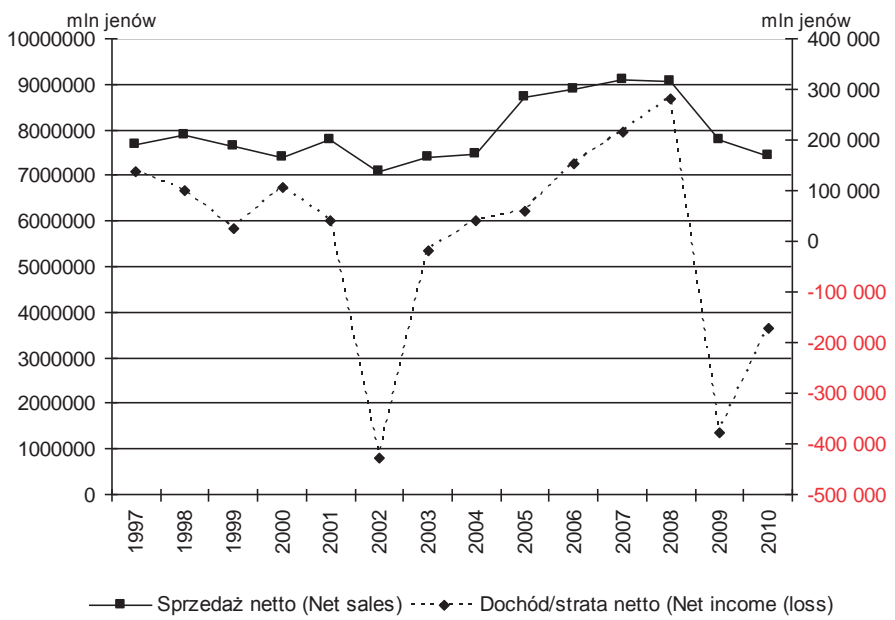

Ryc. 3. Zmiany wartości dochodu netto oraz sprzedaży korporacji

Matsushita Electric Industrial Co. w latach 1997-2010

Źródło: opracowanie własne na podstawie danych ze sprawozdań finansowych firmy

Podobnie jak inne japońskie korporacje informatyczne, takie jak NEC, Hitachi czy Sony, Matsushita Electric musiała podjąć decyzję o redukcji zatrudnienia. Korporacja zanotowała w latach 2007-2009 znaczny spadek liczby zatrudnionych z 328,6 tys. w 2007 r. do 292,2 tys. osób w 2009 roku, tj. do 88,9\% , przy czym od roku 2000 zauważalny jest wzrost zatrudnienia w oddziałach zagranicznych kosztem oddziałów krajowych (ryc. 4, tab. 2) oraz spadek wartości aktywów z 7896,9 mld jenów do 6403,3 mld jenów, tj. do 81,1\% (ryc. 5).

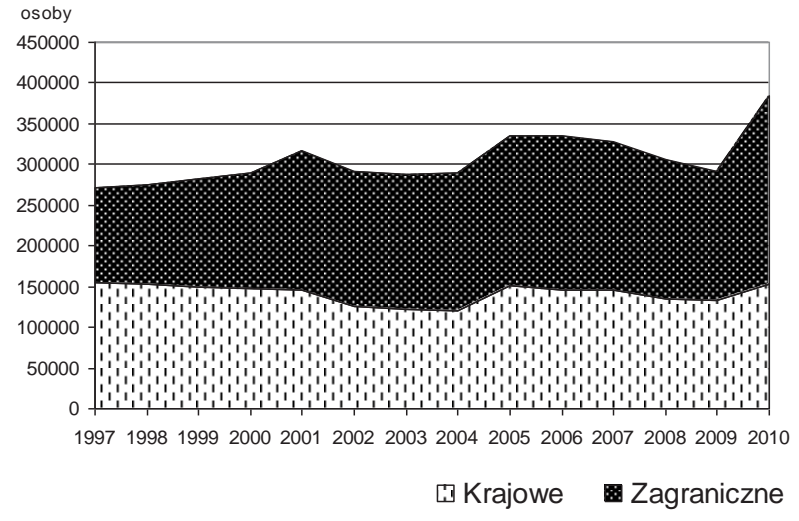

Ryc. 4. Zmiany zatrudnienia krajowego i zagranicznego korporacji

Matsushita Electric Industrial Co. w latach 1997-2010

Źródło: opracowanie własne na podstawie danych ze sprawozdań finansowych firmy 
Tab. 2. Zmiany zatrudnienia korporacji Matsushita Electric Industrial Co.

w oddziałach krajowych i zagranicznych w latach 1997-2010

\begin{tabular}{|c|c|c|c|c|c|}
\hline Lata & $\begin{array}{c}\text { Zatrudnienie } \\
\text { ogółem }\end{array}$ & Krajowe & Zagraniczne & $\begin{array}{c}\text { Udział zatrudnienia } \\
\text { krajowego w ogóle }\end{array}$ & $\begin{array}{c}\text { Udział zatrudnienia } \\
\text { zagranicznego w ogóle }\end{array}$ \\
\hline 1997 & 270651 & 154372 & 116279 & 57,0 & 43,0 \\
\hline 1998 & 275962 & 152270 & 123692 & 55,2 & 44,8 \\
\hline 1999 & 282153 & 148524 & 133629 & 52,6 & 47,4 \\
\hline 2000 & 290448 & 146675 & 143773 & 50,5 & 49,5 \\
\hline 2001 & 317343 & 145150 & 172193 & 45,7 & 54,3 \\
\hline 2002 & 291232 & 126378 & 164854 & 43,4 & 56,6 \\
\hline 2003 & 288324 & 121451 & 166873 & 42,1 & 57,9 \\
\hline 2004 & 290493 & 119528 & 170965 & 41,1 & 58,9 \\
\hline 2005 & 334752 & 150642 & 184110 & 45,0 & 55,0 \\
\hline 2006 & 334402 & 144871 & 189531 & 43,3 & 55,7 \\
\hline 2007 & 328645 & 145418 & 183227 & 44,2 & 55,7 \\
\hline 2008 & 305828 & 135563 & 170265 & 44,3 & 54,8 \\
\hline 2009 & 292250 & 132144 & 160106 & 45,2 & 60,3 \\
\hline 2010 & 384586 & 152853 & 231733 & 39,7 & \\
\hline
\end{tabular}

Źródło: opracowanie własne na podstawie danych ze sprawozdań finansowych firmy

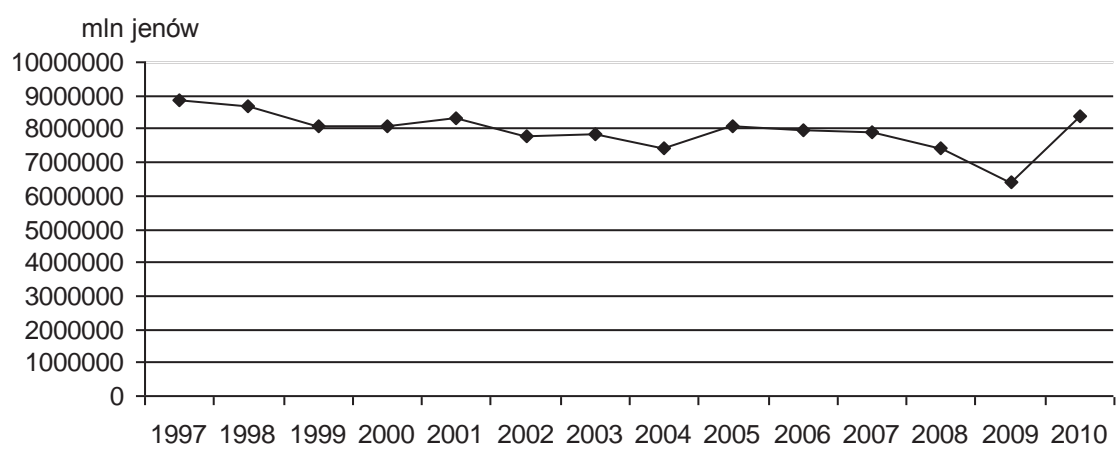

Ryc. 5. Zmiany wartości aktywów korporacji Matsushita Electric Industrial Co. w latach 1997-2010

Źródło: opracowanie własne na podstawie danych ze sprawozdań finansowych firmy

W 2010 r. wartość aktywów i liczba zatrudnionych wzrosły, gdyż w 2009 r. Panasonic wykupił swojego rywala Sanyo Electric ${ }^{1}$. Transakcję przeprowadzono, by obniżyć koszty i poprawić rentowność obydwu firm oraz zwiększyć udział Panasonica w rynku baterii wielokrotnego ładowania (z obecnych 10\% do 38\% ) i wejść na rynek ekologicznych baterii słonecznych.

${ }^{1}$ Warto zaznaczyć, że to przejęcie przypomina o specjalnych powiązaniach pomiędzy firmami, gdyż założyciel Sanyo - Toshio Iue, kuzyn założyciela firmy Panasonic Konosuke Matsushita, pracował wcześniej w firmie Panasonic, skąd odszedł w 1946 r. i rok później założył Sanyo. 
Podjęto szereg działań zmierzających do podniesienia wyników finansowych korporacji. Jednym z nich było przyjęcie 01.08.2008 nazwy jednej z marek firmy dla całej korporacji - Panasonic Corporation. Zmiana nazwy oraz obecnie następująca unifikacja dotychczasowych marek korporacji takich jak: Panasonic, Technics, National, Nais, Quasar, Ramsa, Rasonic, Sanyo, ma przyczynić się do stworzenia globalnego przedsiębiorstwa. Poza tym w 2008 r. sprzedano korporacji Kenwood znaczną część udziałów w firmie JVC, pozostawiając sobie jedynie $20 \%$ udziałów tego przedsiębiorstwa.

Innym zabiegiem, mającym poprawić kondycję ekonomiczną korporacji było wystosowanie okólnika do pracowników wyższego szczebla, w którym jednoznacznie zasugerowano zakupienie produktów firmy Panasonic. Menadżerowie na wyższych stanowiskach mieli kupić sprzęt z logo Panasonic o wartości 200 tys. jenów (2200 dolarów), a średniego i niższego szczebla za 100 tys. jenów (1100 dolarów). Przy czym warto tutaj zaznaczyć, że w japońskich korporacjach (również w Panasonic) funkcjonuje system zwyczajowego dożywotniego zatrudniania menagerów, co jest swego rodzaju mechanizmem opierającym się na długotrwałym zaangażowaniu obu stron we współpracę, co może wyjaśniać przyczyny wystosowania takiego żądania wobec tej grupy pracowników. Ocenia się, że ten tradycyjny system jest bardzo kosztowny, gdyż zatrudniani na takich zasadach menagerowie są uprzywilejowani pod wieloma względami, dlatego w okresie kryzysu gospodarczego podjęto szeroką dyskusję na ten temat w Japonii. W mniejszych firmach odchodzi się obecnie od tego typu praktyk (Jerzewska).

Działania korporacji zostały podzielone na cztery segmenty: AVC Networks, AGD, urządzeń przemysłowych oraz komponentów i urządzeń. Spółki należące do korporacji (jest ich około 540) dostarczają około 15 tys. rodzajów produktów. W swoim asortymencie zawiera zarówno telewizory i DVD, pralki, roboty przemysłowe czy półprzewodniki. Jednakże każda firma ma swoje odrębne segmenty badań i rozwoju, produkcji oraz sprzedaży.

Systematyczne wprowadzanie na rynki światowe coraz to nowocześniejszych produktów jest możliwe dzięki wzmożonym pracom badawczo-rozwojowym prowadzonym przez korporację. W latach 1997-2010 wartość wydatków na ten cel wahała się od 5,7\% do 8\% wartości sprzedaży (ryc. 6).

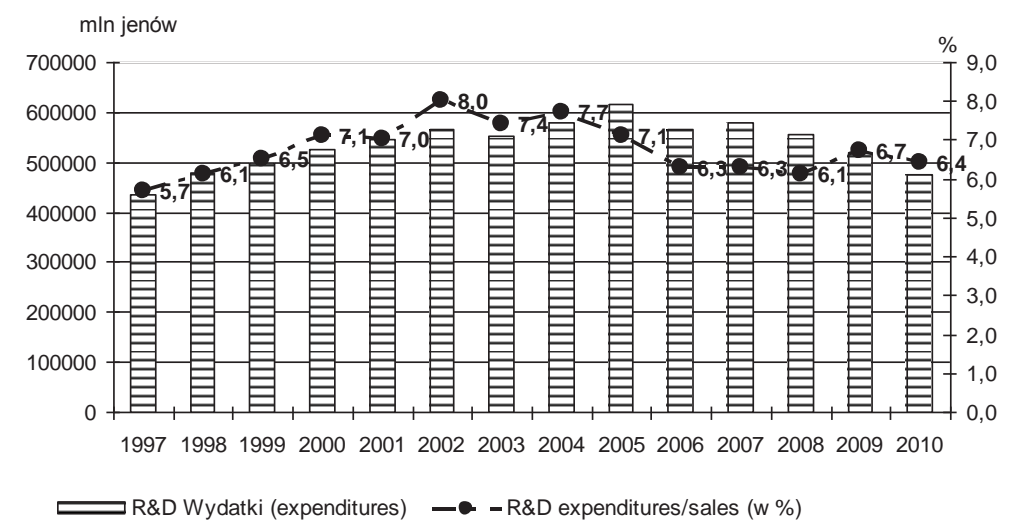

Ryc. 6. Zmiany wartości nakładów na działalność badawczo-rozwojowa oraz stosunek wydatków na tę działalność do przychodów ze sprzedaży korporacji Matsushita Electric Industrial Co. w latach 1997-2010

Źródło: opracowanie własne na podstawie danych ze sprawozdań finansowych firmy 
W świetle przedstawionej analizy można przyjąć, że Panasonic jako jedna z japońskich korporacji na początku światowego kryzysu gospodarczego, podobnie jak korporacje w innych państwach azjatyckich, po kryzysie, jaki miał miejsce w tej części świata w latach 1997-1998, wprowadziła pewne mechanizmy chroniące ją przed nagłą utratą płynności finansowej. Jednakże silne powiązanie ekonomiczne z krajami europejskimi oraz ze Stanami Zjednoczonymi przełożyły się na znaczne pogorszenie sytuacji finansowej tej korporacji w czasie kryzysu w latach 2007-2009, którego skutki odczuwalne są nadal. Podjęte działania wpłynęły na to, że Panasonic zajmuje 24 pozycję wśród 123 wiodących światowych korporacji informatycznych ${ }^{2}$, jest jednym z największych producentów elektroniki konsumenckiej i przemysłowej na świecie.

\section{Literatura}

Czarny E. (red.), 2004, Globalizacja od A do Z, Narodowy Bank Polski, Warszawa www.nbp.pl/publikacje/globalizacja/globalizacja.pdf, (dostęp 31.08.2010).

Domański, B., Gwosdz, K., 2008, Efekty mnożnikowe w rozwoju lokalnym i regionalnym, [w:] Region społeczno-ekonomiczny i rozwój regionalny, red. T. Stryjakiewicz, J.J. Parysek, Bogucki Wydawnictwo Naukowe, Poznań, s. 217-235.

Dorocki S., 2010, Wspótczesne procesy internacjonalizacji produkcji i delokalizacji przemystu samochodowego Francji, [w:] Procesy przemian przemystu i ustug w wybranych krajach, red. Z. Zioło, T. Rachwał, Prace Komisji Geografii Przemysłu PTG, nr 16, Wydawnictwo Naukowe UP, Warszawa-Kraków, s. 125-136.

Flejterski S., 2010, Globalny kryzys bankowo-finansowy. Geneza, aktorzy, konsekwencje, [w:] Globalizacja, kryzys i co dalej?, red. G.W. Kołodko, Wydawnictwo Poltext, Warszawa, s. 134-154.

Jerzewska A., Perspektywy japońskiego modelu zarządzania zasobami ludzkimi - krytyczna ocena Trzech Świętych Skarbów, [w:] http://www.orient.umk.pl/publikacje/3ss.pdf

Kalicki K., Krześniak A., 2010, Polityka pieniężna w strefie euro i USA a ceny aktywów w świetle doświadczeń kryzysu, [w:] Globalizacja, kryzys i co dalej?, red. G.W. Kołodko, Wydawnictwo Poltext, Warszawa, s. 155-185.

Kilar W., 2010, Procesy ksztaltowania sie korporacji Ericsson, [w:] Procesy przemian przemystu i usług w wybranych krajach, red. Z. Zioło, T. Rachwał, Prace Komisji Geografii Przemysłu PTG, nr 16, Wydawnictwo Naukowe UP, Warszawa-Kraków, s. 153-168.

Kutera M., Surydykowska S.T., 2009, Kryzysy gospodarcze a wiarygodność sprawozdań finansowych, Difin, Warszawa.

Michalski R., 2010, Globalny kryzys finansowo-gospodarczy a zmiana uktadu sit w gospodarce i finansach świata, [w:] Globalizacja, kryzys i co dalej?, red. G.W. Kołodko, Wydawnictwo Poltext, Warszawa, s. 317-337.

Rachwał T., 2009, Changes of industry in the countries of Central and Eastern Europe under conditions of economic transformation and european integration, [w:] Countries of Central \& Eastern Europe versus global economic Crisis, red. J. Kitowski, Geopolitical Studies, vol. 15, Wyd. Instytut Geografii i Przestrzennego Zagospodarowania PAN, Warszawa, s. 133-164.

Rachwał T., 2010, Struktura przestrzenna i działowa przemystu Polski na tle Unii Europejskiej w dwudziestolecie rozpoczęcia procesów transformacji systemowej, [w:] Procesy przemian przemystu i usług w wybranych krajach, red. Z. Zioło, T. Rachwał, Prace Komisji Geografii Przemysłu PTG, nr 16, Wydawnictwo Naukowe UP, Warszawa-Kraków, s. 103-124.

Rosati D., 2010, Przyczyny i mechanizmy kryzysu finansowego w USA w latach 2007-2009, [w:] Globalizacja, kryzys i co dalej?, red. G.W. Kołodko, Wydawnictwo Poltext, Warszawa, s. 103-133.

\footnotetext{
${ }^{2}$ Wg rankingu Forbes Global 2000 z 2010 r.
} 
Trzpil M., 2009, Kryzys finansowy w wybranych państwach Azji, Bezpieczeństwo Narodowe, nr 9-10, s. $131-142$.

Wiedermann K., 2007, Regionalne efekty mnożnikowe rozwoju przemyslu motoryzacyjnego w aktywizacji gospodarczej województwa ślaskiego, [w:] Rola przedsiębiorczości w aktywizacji gospodarczej, red. Z. Zioło, T. Rachwał, Przedsiębiorczość - Edukacja, nr 3, Zakład Przedsiębiorczości i Gospodarki Przestrzennej IG AP, Wydawnictwo Nowa Era, Warszawa-Kraków, s. 24-34.

Wiedermann K., 2008, Koncepcja efektów mnożnikowych $w$ wyznaczaniu wpływu przedsiębiorstw na otoczenie spoleczno-gospodarcze, [w:] Problematyka badawcza geografii przemystu, red. Z. Zioło, T. Rachwał, Prace Komisji Geografii Przemysłu PTG, nr 11, Komisja Geografii Przemysłu PTG, Wydawnictwo Naukowe AP w Krakowie, Warszawa-Kraków, s. 98-106.

Wajda E., 2003, Proces ksztaltowania się Motoroli jako firmy ponadnarodowej, [w:] Kształtowanie się struktur przemysłowych, red. Z. Zioło i Z. Makieła, Prace Komisji Geografii Przemysłu PTG, nr 5, Komisja Geografii Przemysłu PTG w Warszawie i Instytut Geografii Akademii Pedagogicznej w Krakowie, Warszawa-Kraków, s. 85-114.

Wajda E., 2006, Rozwój i struktura przestrzenna działalności Nokii w latach 1997-2003, [w:] Międzynarodowe uwarunkowania rozwoju przemystu, red. Z. Zioło i T. Rachwał, Prace Komisji Geografii Przemysłu PTG, nr 8, Komisja Geografii Przemysłu PTG w Warszawie i Zakład Przedsiębiorczości i Gospodarki Przestrzennej Instytutu Geografii Akademii Pedagogicznej w Krakowie, Warszawa-Kraków, s. 219-240.

Wajda E., 2003, Zoričič-Wołek M., Proces kształtowania się korporacji IBM, [w:] Przemysł w procesie globalizacji, red. Z. Zioło i Z. Makieła, Prace Komisji Geografii Przemysłu PTG, nr 6, Komisja Geografii Przemysłu PTG w Warszawie i Zakład Przedsiębiorczości i Gospodarki Przestrzennej Instytutu Geografii Akademii Pedagogicznej w Krakowie, Warszawa-Kraków, s. 109-118.

Zioło Z., 2008, Procesy transformacji przemysłowych układów przestrzennych na tle zmieniajacego się otoczenia, [w:] Procesy transformacji uktadów przestrzennych przemystu na tle zmieniajacego się otoczenia, red. Z. Zioło i T. Rachwał, Prace Komisji Geografii Przemysłu PTG, nr 10, Komisja Geografii Przemysłu PTG i Zakład Przedsiębiorczości i Gospodarki Przestrzennej Instytutu Geografii Akademii Pedagogicznej w Krakowie, Warszawa-Kraków, s. 11-22.

http://www.fundinguniverse.com/company-histories/Matsushita-Electric-Industrial-Co-LtdCompany-History.html (dostęp 25.11.2010)

\section{The impact of the crisis on the functioning of Panasonic corporation}

The purpose of the article is to present the analysis of the influence of economic crisis on the functioning of one of the Japanese IT corporations - Panasonic. The paper aims at specifying changes in Panasonic's economic potential, and at presenting actions taken in order to improve its financial situation. After the crisis which took place in this part of the world in years 1997-1998, Panasonic (like many other corporations in Asia) introduced some mechanisms of protecting the company against the sudden loss of financial liquidity. Strong economic ties with European countries, as well as with the USA, resulted in significant deterioration in this corporation's financial situation during the crisis in years 2007-2009. Nonetheless, the undertaken actions allowed it to remain one of the largest manufacturers of consumer and industrial electronics in the world.

Mgr Wioletta Kilar

Uniwersytet Pedagogiczny, Kraków

Instytut Geografii

Zakład Przedsiębiorczości i Gospodarki Przestrzennej

e-mail: W.Kilar@up.krakow.pl 